\title{
The Benefits and Challenges of Special Education Positions in Rural Settings: Listening to the Teachers
}

\author{
Ann B. Berry \\ Plymouth State University \\ Maggie Gravelle \\ University of North Carolina, Chapel Hill
}

Special education teachers, through a national survey conducted in 55 rural districts, provided information on the positive and negative aspects of teaching in rural schools. The 203 special educators were asked what they liked best about their position and what they found challenging. Some of the themes identified in the analysis centered on positive features of working in rural areas. Characteristics of the rural community fostered family-like relationships with others in their school and in-depth relationships with parents and students. Half of the teachers also reported they shared the responsibility or took a team approach to delivering special education services, a factor related to teacher satisfaction. The majority of teachers were satisfied with the instructional aspects of their position but dissatisfied with non-instructional role responsibilities. Challenges of the position also included role confusion and a lack of resources. Related implications for rural administrators interested in the satisfaction of special education teachers are provided.

Key Words: Rural education, special education teacher satisfaction, rural challenges, rural advantage

Research in the field of special education has highlighted several work-related challenges (e.g., role confusion, role conflict, paperwork, inadequate support), which can adversely affect special educators' sense of satisfaction with their positions (Billingsley, 2004a). In addition, there are characteristics of the position inherent to working in rural settings (e.g., geographic isolation, professional isolation, diversity of caseloads), which may contribute to the difficulty some administrators experience recruiting and retaining special educators to positions in rural districts (Provasnik et al., 2007; Schwartzbeck, Prince, Redfield, Morris, \& Hammer, 2003). In fact, the shortage of highly qualified special educators in rural areas is reported to be as high as 35\% (Brownell, Bishop, \& Sindelar, 2005). Despite these challenges, research has also highlighted work-related benefits to teaching in rural settings (e.g., smaller class size, greater parent involvement), which may contribute to teacher satisfaction (Provasnik et al.). Teacher satisfaction is important not only because it is related to teacher attrition and poses a threat to the continuity of education services but also because teacher satisfaction can have an impact on the quality of the education students with disabilities receive
(Brownell, Sindelar, Kieley, \& Danielson, 2010; Whitaker, 2000). As teacher satisfaction also plays a significant role in the overall climate of the school, factors that influence teacher satisfaction become critical information when seeking to create positive school environments (Gersten, Keating, Yovanoff, \& Harniss, 2001).

This study seeks to identify features of the special education position related to teacher satisfaction. To this end, it examines the perceptions of special education teachers in rural areas related to: (a) what they like best about teaching in rural schools; (b) the challenges and reasons for dissatisfaction with their position; and (c) information on support variables, specifically, a shared responsibility for delivering services to students on their caseload. The aim is to provide an understanding of the unique benefits and challenges of special education positions in rural areas. It is hoped that such information may be helpful to rural administrators by highlighting factors related to teacher satisfaction and thus strengthen their ability to foster positive working conditions in their schools. The literature review that frames the study outlines many positive and negative aspects of teaching in rural areas. 


\section{Positive Aspects of Teaching in Rural Schools}

Rural school communities have many positive qualities that can influence the satisfaction of special education teachers. Rural teachers, for example, often report positive relationships with their students and parents, as well as an appreciation of the rural lifestyle (Davis, 2002). Provasnik and her colleagues (2007), using data provided by the National Center for Educational Statistics (NCES), found that compared to teachers working in urban locales, a larger percentage of teachers working in rural areas, were satisfied with their class size, their students' behavior, and the support they received from parents. Students in rural districts more frequently came to school prepared to learn and had fewer student behavior problems. Parents were more frequently involved in parent and teacher conferences and school events.

Research in rural education has highlighted additional qualities found in small, rural schools that positively impact teacher satisfaction. Malloy and Allen (2007) studied one rural elementary school with a low teacher attrition rate (6\% versus $20 \%$ in the district and $19 \%$ in the state). The staff fostered a family-like atmosphere (e.g., making personal phone calls to each other in times of stress). The school emphasized collaboration among staff (e.g., team teaching, mentoring, peer coaching and evaluation) and administrators were reported as being caring and approachable. The non-threatening environment encouraged questions from new faculty and promoted opportunities for teachers to discuss issues with experienced colleagues. Similarly, in one rural district in Florida, teachers stated the sense of knowing each other well was the quality of working in a small school community they enjoyed most (Huysman, 2008). The presence of a cohesive school community was important for these teachers working in their small, rural school.

Nagle, Hernandez, Embler, McLaughlin, and Doh (2006), investigating 13 high schools with high levels of staff stability in three rural states, found that an attitude of collective responsibility within the school was also important to teacher satisfaction. Students with disabilities were often educated in the general education classroom and the staff shared the responsibility for educating all students, both special education and general education students. Teachers of general and special education described close relationships with each other and a high degree of collaboration. This was facilitated by a shared planning time for teachers and team meetings once a week. Building administrators were also very involved with special education processes and supported a positive working relationship between teachers.

\section{Challenges of Teaching in Rural Areas}

The remote locations and geographically large districts of some rural areas pose distinct challenges for special educators. In rural special education, the low incidence of special needs populations can mean smaller caseloads, but can also mean teachers are one of few special educators in their school or district, or even the only special educator providing services in several schools. Special educators in remote locations frequently report professional and social isolation as a challenge of their position (Collins, 1999). Additionally, the transition to a rural area, where the social and cultural activities typically associated with larger urban districts are not available, can be difficult for new teachers (Bornfield, Hall, Hall, \& Hoover, 1997).

The characteristics of the special needs population create additional challenges for rural special educators. In some small rural school districts, special education teachers provide instruction to students in kindergarten through 12th grade across a variety of subjects (Schwartzbeck et al., 2003). Special educators are often asked to address a wide variety of student needs and disability categories in rural schools, resulting in a need for teachers to work outside of their typical training and expertise (Brownell et al., 2005).

Many rural schools operate within a more restricted budget because of a lower tax base in these areas (Monk, 2008). Limited operating budgets in rural schools present additional challenges for rural special education teachers. Teachers may need to make do with fewer materials and resources due to budget constraints. Rural schools may struggle to provide the specialized services required by individualized programs. As a result, small schools may be forced to consolidate services or hire outside agencies to provide services for their students with special needs (Hodge, \& Krumm, 2009). 
Historically, teachers in rural areas have experienced lower pay scales, fewer support networks, and limited professional development opportunities because of their schools' limited resources (Collins, 1999;

Ludlow, Conner, \& Schechter, 2005).

Further, the federal mandates of No Child Left Behind (NCLB, 2001) for student progress can be discouraging for special educators in rural areas. Despite the teachers' effectiveness, a small number of special needs students can create artificial volatility in achievement scores, hindering the school's ability to meet adequate yearly progress (AYP). Being marked as an In Need of Improvement school can create a demoralizing environment for special educators. NCLB sanctions (e.g., fewer federal funds, reassignment of money, or the option of school choice) can strain an already stretched school budget as administrators struggle to recruit and compete with the better salaries, student services, and teacher programs found in other parts of the state (Brownell et al., 2005; Jimerson, 2005).

It appears that special education teachers who work in small and rural communities may have fewer professional sources of support available to them thus increasing their sense of professional isolation. In a recent national study, researchers examined the relationship of work-related support to special education teacher satisfaction in rural districts (Berry, 2012). One key support variable, the support provided by other special educators, was not always available. However, teachers who were resourceful had a wider network of support from available sources such as administrators and general education colleagues; these teachers reported greater levels of satisfaction. Job satisfaction was also found to increase if others in the school understood the special educator's role and responsibilities and if others shared in the responsibility of providing services to students with disabilities.

In summary, research has indicated that small, rural school environments have positive qualities and apparent challenges that can influence special education teachers' satisfaction with their position. However, only a small number of studies investigating factors related to teacher satisfaction specifically focus on the rural special education teacher. Studies that have investigated rural teachers were generally conducted in a centralized region or single state. Research conducted on a national scale that analyzed rural special education teachers' perceptions of their positions would provide vital information related to teacher satisfaction.

This study was guided by the following research questions: What do special education teachers report they like best about their current position in rural schools? What do they perceive as the challenges of working in rural schools? What do teachers cite as reasons for dissatisfaction with instructional or noninstructional aspects of their job? Do special education teachers state they shoulder the entire responsibility of educating students with disabilities on their caseload or do they share this responsibility? What are the contributors to this perception?

\section{Method}

During the 2008-2009 and 2009-2010 school years, special educators from a national sample of rural school districts provided data for this study. Data reported here were collected from responses to open-ended questions related to special education teachers' perceptions of satisfaction and support in their positions. These questions were part of a larger survey with quantitative items that have been reported separately (Berry, 2012). The following sections outline procedures for sample selection, teacher characteristics, survey administration, and data analysis.

\section{Sample Selection}

Participants were special education teachers from rural school districts in 33 states. Rural districts were identified in the following way: first regular public school districts were identified from the NCES Common Core of Data (Version 1a: NCES, 2006). Districts were then identified as rural in several ways: (a) their eligibility in either the Rural Education Achievement Program or the Rural and Low-Income Schools Program; (b) they were designated with a rural NCES metro-centric code (i.e., 7 or 8); or (c) had a rural NCES urban-centric code (i.e., 41 for rural fringe, 42 for rural distant, or 43 for rural remote).

Fifty-five districts were then randomly selected from these rural districts. Sixteen of the districts were in rural fringe locale codes and located near an urban cluster, 23 were categorized as rural distant 
(i.e., 5 to 25 miles from an urban area) and 16 were in rural remote areas (i.e., more than 25 miles from an urban center). Additional characteristics of the districts are outlined in Table 1.

Researchers utilized district websites and administrators to identify all special education teachers in each district. A letter of introduction was sent to each special education teacher explaining the aims of the study. Teachers were then contacted by telephone and invited to participate in the research. A cap of 10 teachers per district was imposed to avoid over-representation of the sample by larger districts.

From a pool of 522 special education teachers in the 55 districts, 159 were found ineligible either because they were not special educators (e.g., worked as a paraprofessional or school psychologist) or the cap of teachers had been reached for the district. Interviewers were able to contact 243 teachers by telephone, resulting in a response rate of $67 \%$ (i.e., 243/363). A total of 204 teachers agreed to participate in the study for a participation rate of $84 \%$ (i.e., 204/243; Berry, 2012).

\section{Table 1}

Composition of District Sample $(\mathbf{N}=\mathbf{5 5})$

\begin{tabular}{|c|c|c|c|c|c|c|}
\hline \multirow[t]{2}{*}{ Category } & \multirow{2}{*}{$\begin{array}{l}\text { Number of } \\
\text { districts in } \\
\text { category } \\
(\%)\end{array}$} & \multirow{2}{*}{$\begin{array}{l}\text { Average } \\
\text { student } \\
\text { population } \\
\text { (range) }\end{array}$} & \multirow{2}{*}{$\begin{array}{l}\text { Average } \\
\text { number of } \\
\text { schools } \\
\text { (range) }\end{array}$} & \multicolumn{3}{|c|}{$\begin{array}{l}\text { Number of districts in } \\
\text { NCES local code }\end{array}$} \\
\hline & & & & Remote & Distant & Fringe \\
\hline $\begin{array}{l}\text { Small Rural School } \\
\text { Achievement Program }\end{array}$ & $\begin{array}{c}20 \\
(36 \%)\end{array}$ & $\begin{array}{c}373 \\
(72-1,020)\end{array}$ & $\begin{array}{c}2.3 \\
(1-6)\end{array}$ & 7 & 10 & 3 \\
\hline $\begin{array}{l}\text { Rural and Low-Income } \\
\text { Schools Program }\end{array}$ & $\begin{array}{c}11 \\
(20 \%)\end{array}$ & $\begin{array}{c}2,719 \\
(632-7137)\end{array}$ & $\begin{array}{c}7 \\
(3-14)\end{array}$ & 2 & 7 & 2 \\
\hline NCES Rural & $\begin{array}{c}24 \\
(44 \%)\end{array}$ & $\begin{array}{c}2,229 \\
(131-11,047)\end{array}$ & $\begin{array}{c}4.8 \\
(2-17)\end{array}$ & 7 & 6 & 11 \\
\hline
\end{tabular}

\section{Teacher and Position Characteristics}

As can be seen in Tables 2 and 3, special education teachers in this sample were typical of those found in other rural research (Bornfield et al.,1997; Davis, 1992). The majority of teachers $(62 \%)$ had lived in their rural area for 16 years or more, and nearly half were teaching in a school located in the same general area as the place where they grew up. Teachers held certifications and taught in more than one grade level. Most (80\%) had small caseloads (i.e., fewer than 20 students) with an average of 15 students. Teachers in the sample had a wide range of experience. Most teachers (62\%) held their state's highest level of certification in special education and were considered highly qualified. Half of the teachers had been teaching in the field of special education for more than 10 years, and 33\% more than 16 years (Berry, 2012). One rural teacher had been working in the field of special education for 32 years. In some districts the special education teacher was the only special educator in the district and divided his/her time between two or three buildings, whereas in other districts the special educator was one of many special education teachers in a large consolidated district. 
Table 2

Teacher Demographics $(\mathrm{N}=\mathbf{2 0 3})$

\begin{tabular}{lccccc}
\hline $\begin{array}{l}\text { Characteristic } \\
\text { M (SD) }\end{array}$ & $\begin{array}{c}\text { New } \\
1-2 \mathrm{yrs}\end{array}$ & $\begin{array}{c}\text { Beginning } \\
3-5 \mathrm{yrs}\end{array}$ & $\begin{array}{c}\text { Early } \\
6-10 \mathrm{yrs}\end{array}$ & $\begin{array}{c}\text { Mature } \\
11-15 \mathrm{yrs}\end{array}$ & $\begin{array}{c}\text { Veteran } \\
16-20+\mathrm{yrs}\end{array}$ \\
\hline $\begin{array}{l}\text { Years in position } \\
7.8(.8)\end{array}$ & $30 \%$ & $27 \%$ & $18 \%$ & $10 \%$ & $16 \%$ \\
$\begin{array}{l}\text { Years in special } \\
\text { education }\end{array}$ & $10 \%$ & $16 \%$ & $24 \%$ & $14 \%$ & $33 \%$ \\
$\begin{array}{l}12.9(9) \\
\text { Years living in rural }\end{array}$ & $7 \%$ & $8 \%$ & $16 \%$ & $7 \%$ & \\
$\begin{array}{l}\text { area } \\
22.2(15)\end{array}$ & & & & \\
Age in years & & & & & \\
$43(11)$ & $20-29$ & $30-39$ & $40-49$ & $50-59$ & $>60$ \\
\end{tabular}

Table 3

Position Characteristics $(\mathrm{N}=\mathbf{2 0 3})$

\begin{tabular}{|c|c|c|c|c|c|}
\hline$\%$ teachers with & $\mathrm{K}-5$ & $6-8$ & $9-12$ & & \\
\hline $\begin{array}{l}\text { special education } \\
\text { certification }\end{array}$ & $60 \%$ & $62 \%$ & $50 \%$ & & \\
\hline $\begin{array}{l}\text { Primary instructional } \\
\text { setting }\end{array}$ & $\begin{array}{l}\text { Self- } \\
\text { contained } \\
25 \%\end{array}$ & $\begin{array}{l}\text { Resource } \\
\text { Room } \\
53 \%\end{array}$ & $\begin{array}{l}\text { Inclusion } \\
\text { classroom } \\
18 \%\end{array}$ & $\begin{array}{c}\text { Classroom } \\
\text { consultant } \\
4 \%\end{array}$ & \\
\hline Students on caseload & $2-10$ & $11-15$ & $16-20$ & $20-25$ & $26-40$ \\
\hline Mean 15.2 (SD 8) & $30 \%$ & $27 \%$ & $23 \%$ & $10 \%$ & $10 \%$ \\
\hline Grade level & $\begin{array}{c}\mathrm{K}-5 \\
54 \%\end{array}$ & $\begin{array}{c}6-8 \\
41 \%\end{array}$ & $\begin{array}{c}9-12 \\
25 \%\end{array}$ & & \\
\hline $\begin{array}{l}\text { Highest level of } \mathrm{SpEd} \\
\text { certification for their } \\
\text { state }\end{array}$ & $\begin{array}{l}\text { Yes } \\
62 \%\end{array}$ & $\begin{array}{l}\text { No } \\
30 \%\end{array}$ & $\begin{array}{c}\text { Don't know } \\
8 \%\end{array}$ & & \\
\hline $\begin{array}{l}\text { Highest level of } \\
\text { education }\end{array}$ & $\begin{array}{c}\mathrm{BA} / \mathrm{BS} \\
35 \%\end{array}$ & $\begin{array}{l}\text { MS/MEd } \\
64 \%\end{array}$ & $\begin{array}{c}\text { Other } \\
1 \%\end{array}$ & & \\
\hline $\begin{array}{l}\text { Teacher } \\
\text { licensure }\end{array}$ & $\begin{array}{c}\text { Traditional } \\
83 \%\end{array}$ & $\begin{array}{c}\text { Alternative } \\
14 \%\end{array}$ & $\begin{array}{l}\text { Other } \\
3 \%\end{array}$ & & \\
\hline $\begin{array}{l}\text { Grew up in } \\
\text { rural area }\end{array}$ & $\begin{array}{l}\text { Yes } \\
48 \%\end{array}$ & $\begin{array}{l}\text { No } \\
52 \%\end{array}$ & & & \\
\hline
\end{tabular}

Note: BA/BS Bachelor degree; MS/MEd Master degree 


\section{Procedures}

Seven interviewers conducted phone interviews of 35 to 90 minutes in length with the teachers. Interviewers were two researchers from the National Center on Rural Education Support (NCRES) who had extensive training and experience in survey implementation, and five university graduate assistants. Interviewers were trained prior to the start of the study and three periodic checks for drift with these procedures were conducted over the nine months of the study. Reliability rates for adherence to the script and accuracy of response recording was 95\% or higher (Berry, 2012). During the interview, a script was read and teacher responses were typed directly into a computer database. Additionally, interviewers were trained to verify that the recorded answer accurately represented the teacher's views by reading the recorded response aloud (i.e., member checking) following the teacher's response to each item. If teachers provided additional information to expand or clarify their responses, the interviewer would type that information into the database.

\section{Data Analysis}

Coding for the teacher responses was developed in a structured and logical way. Data were compiled by question in a table containing each teacher's response. One researcher from NCRES and one doctoral student coded data into topic areas generated from prior research in rural special education investigating special education teacher job satisfaction (Downing \& Peckham-Hardin, 2007; Gehrke \& McCoy, 2007; Malloy \& Allen, 2007; Nagle et al., 2006). Categories emerged from the teacher responses (e.g., small school size, relationship with staff, relationship with students, paperwork), as researchers accounted for new relationships. Data were then re-categorized as connections both within and across items developed and new constructs emerged (e.g., shared responsibility with general educators, related service providers). This across-case analysis method was used to identify pervasive patterns and themes (Miles \& Huberman, 1994). The code number(s) for each category were recorded beside each teacher's response.
To assure that open-ended responses were coded with reliability, the two coders independently coded all responses from a subset of randomly selected districts. The coded responses for these districts were compared and inter-coder reliability (i.e., number of agreements divided by the total number of agreements plus disagreements) was $93 \%$ percent. Differences in coding were discussed and a consensus was reached. The remaining districts were then coded independently. Subsequent reliability checks ranged from 90 to $97 \%$ agreement with an average of $94.5 \%$. Descriptive statistics were compiled based on the frequency and variety of teacher responses to address the research questions under investigation.

\section{Findings}

Special educators in 55 rural districts conveyed to researchers what they liked best and what they found challenging about teaching in special education. Additionally, teachers reported on factors related to their satisfaction and dissatisfaction with their positions.

\section{What Teachers Liked Best}

Teachers talked about many aspects of their school and community when asked what they liked best about being a special educator in a small and rural school. Some of the major themes identified were positive characteristics generally associated with being a special education teacher whereas others were characteristics of being a teacher in a rural school.

Teaching in special education. Some of the teachers (14\%) talked about positive aspects of working in the field of special education. For example, one teacher remarked, I like working in small groups and learning each of my kids learning styles in order to make the curriculum fit with their own unique ways. These teachers enjoyed watching their students make progress from year to year. I enjoy working with this population of students, explained one teacher. "I feel I can really make a difference and improve their lives, whatever their disabilities. 
Teaching in a rural school. The majority of the teachers $(86 \%)$, however, when asked about what they liked best about their special education position, discussed aspects of the position related to teaching in a rural school. Teachers indicated that the smaller size of their rural community made possible positive relationships with others in their school community, with their students' parents, and with their students.

Almost one third (31\%) of the special education teachers conveyed a family-like, supportive community in their school. The staff is a very big support to each other through personal and professional crisis, said one teacher of students with severe disabilities. Everyone works together like a team for a common goal. There is a lot of helping each other out in our school. Another teacher agreed: I like the feeling of being connected to everyone because it is small enough. You see everybody and have to work with everybody.

The special education teachers talked about forming close bonds with staff and these relationships provided a sense of professional support, which teachers appreciated. One teacher's remark represents this group.

I love this job after being in a big district for 15 years and how impersonal it was there. There is something about this small district that is caring and supportive and you get the sense that we are working together. We are very lucky in this school, [there is a] very supportive administration and special ed [ucation] staff. It's all about the kids and not about the scores. It's like a family rather than a corporation.

A climate of acceptance was reported, which had a positive effect on student interactions. For example, one elementary teacher remarked:

The acceptance of my students by everyone in the school [is what I like best]. I love the feeling that your school is like a small family or small community, and everyone is supportive and accepting of the kids with disabilities specifically. I go out to recess and I can't tell which kids are mine. I taught in a larger school near [name of large city] and it wasn't like that at all... It is a really good experience here.

The small size of the school also lent itself to an in-depth, personal knowledge of the students and their families. Twenty-eight percent of teacher comments communicated the opportunity in a rural school to watch students grow up from year to year, and see them in a variety of academic and nonacademic contexts. You get to know the kids and the families really well in a small town, remarked one teacher in this group. That is really nice. I think being in a city school this would be more difficult. Another teacher had similar comments.

I develop a good strong relationship [with students], as I have them for 2 to 3 years and get a chance to be part of their lives. I am a surrogate mother and a friend. I also get to know the parents really well. This year they have been supportive. In the larger district I didn't have this type of rapport with parents. Here, they stop by or you see in the hallway. We talk in the parking lot at the store. It's neat. One teacher briefly summarized the family atmosphere that can be part of a rural school: I know the entire school, every face, every name. These positive aspects of working in a small and rural school also translated to sustaining teachers in their positions. One fourth grade resource room teacher commented:

I think the reason I have been a special education teacher for 26 years is because of the emotional support and friendships that are here in this school. Probably the reason I have been here this long is because of the friendships with the other teachers that extend beyond my professional relationships at school.

Some teacher comments (16\%) discussed positive aspects of working in a rural area. The kids are more considerate and anxious to learn here. They are hardworking and there is not a lot of competition among them about clothing or social status. [There are] less behavioral concerns than you would probably see in a city school. Half of the special education teachers had been raised in their rural area and so personal ties contributed to school pride and a sense of community. As stated by one teacher, I graduated from this school. It is home.

\section{Challenges to the Position}

When special educators were asked specifically about the challenges they encountered being a special education teacher in a rural school, several major themes emerged from the data. Teachers raised issues widely acknowledged by special educators in 
general (e.g., parents, role responsibilities, paperwork, testing, the lack of time) and some issues specific to a rural context.

Teaching in special education. One of the most frequently mentioned challenges $(21 \%)$ involved students' parents. Parents are one of my biggest challenges, said one teacher of students with behavior disorders. She continued:

You can help them with the 6 hours that you have them, but you can't do much about the 18 hours that you don't have them. So much of what these kids come to school with is dependent on what happens at home.

Seventeen percent of special education teachers' comments concerned the responsibilities of their job. As one elementary resource room teacher noted.

Scheduling [is a challenge] - getting to see all the

kids in the time you need to see them so you are not pulling kids from the things they need to be there for in the regular classroom. It's a nightmare.

The teachers expressed frustration with the lack of support provided by general education teachers. Support from the general ed [ucation] teachers is limited, one teacher said. Some teachers don't feel my kids should be in their classroom if they are not able to do everything the regular education students $d o$. Some of the frustration was related to poorly defined roles and responsibilities in the general education classroom. Typical comments were, $\mathrm{Co}$ teaching it is not easy. Educational views and the ways that you teach can clash.

A few (8\%) of special educators commented on federally imposed responsibilities: paperwork, state assessments, and meeting required benchmarks. One resource teacher said:

Meeting the fantasy of NCLB [is the biggest challenge]. We just took our statewide assessment, and we were listed as a failing school because of my students. A six-month gain is a big deal in my experience, but because they didn't make 3 years growth, I didn't do my job. It is discouraging.

Fifteen percent of teachers' comments referenced the lack of time or the lack of staff to adequately perform the duties of the special education position and meet students' needs. The lack of help and time [are challenges]. If the caseloads were smaller, and you had more time to go into classrooms and work with students more, that would be helpful.

Teaching in a rural school. Some of the challenges mentioned were specifically connected to teaching in a small and rural school $(26 \%)$. The small size of the community contributed to the difficulty special education teachers had separating personal and professional lives. It's a small town and rumors spread, commented one teacher, so those lines get blurred professionally and confidentiality is a little harder. Teachers discussed the professional isolation created by teaching in a rural district with large distances to travel to get to trainings. Teachers voiced concerns about inadequate school resources: services, programs, staff, combined classrooms, and larger caseloads. As one resource room teacher commented, Because you are stretched for time you can't be there the way you want to. I am the only special educator in the building. Another teacher of a self-contained classroom explained:

The diversity in the classroom [is a challenge]. I have $L D, B D, M R$, and autistic with one assistant. It is very difficult as it is hard to deal with all those classifications and personalities in one classroom. You don't have the options that might be available in a larger district. You've got to take care of it yourself.

A small percent (2\%) of special educators raised concerns about low salaries.

Even though the smaller size of the school meant limited budgets, teachers also commented on providing services to students, despite limited financial resources. A fifth grade teacher's remark was representative:

Our special education coordinator is very helpful... For example we have a student who has a hearing impairment and we are getting an amplifying system for that student. Some people might think that type of thing might not happen in a small school like we have. It might take a while, but whatever a student might need, we try real hard to provide that.

\section{Satisfaction}

Special education teachers' responses about satisfaction spanned instructional and noninstructional areas of their position. 
Satisfaction with instructional aspects. Most of the special education teachers (89\%) indicated that they were either satisfied or strongly satisfied with the instructional aspects of teaching and delivering services to students on their caseload. Within the group who were dissatisfied, teachers provided several reasons for dissatisfaction, including workload demands (4\%) and not enough time to meet the demands of the role (2\%). For example, one middle school teacher stated, I feel the kids need more time to work on their skills. I just don't get enough time with them.

Satisfaction with non-instructional aspects. A large majority $(67 \%)$ of the special education teachers indicated they were dissatisfied with the non-instructional aspects of teaching. Many teachers (43\%) specifically mentioned the paperwork involved with the job. Paperwork! said one teacher, whose comments represented the overall sentiment. There is more and more and it accomplishes less and less. It takes away from the time with the kids. Seventeen percent of the teachers who expressed dissatisfaction commented on the time demands of the special education job (i.e., record keeping, writing reports, etc.). These responsibilities demanded so much time that they had to be accomplished on personal time. A few $(2 \%)$ teachers mentioned the lack of support from others in the school.

\section{Shared Responsibility}

Researchers also examined whether special education teachers believed they shouldered the entire responsibility for providing services to students on their caseload or shared that responsibility. Half of the teachers $(51 \%)$ said that they had sole responsibility for students with disabilities. One special educator who worked with students with more severe disabilities made statements reflecting the sentiments of these teachers. It is all me, she said. If I don't speak for them it isn't going to happen. I need to advocate for my students constantly.

Special educators provided a variety of reasons for perceiving that they shouldered the entire responsibility of educating their students. Thirty-four percent of the teachers conveyed a lack of support from others in their school. A few of these teachers cited state testing and school sanctions as adding to their sense of professional isolation. As one teacher remarked,

If some students are not passing classes... then the pressure is on me to get...the grades up. The other special educators also put pressure on me. This should be more of a team effort. There is a lot of accountability going on with being a Need of Improvement School and it [the responsibility] all falls to me.

Other teachers in this group talked about role confusion, for example, general education teachers who did not fully understand their role. One comment was: We are still in transition to coteaching and ultimately we are training the general educators to think differently. But the general educators refer to the students as 'your kids' when I am in their classroom.

Nine percent of the special education teachers acknowledged that others helped in their work with identified students but ultimately felt it was their responsibility to see that services were provided. Others (5\%) specifically cited a legal responsibility for IEP implementation as the reason they believed the responsibility was theirs.

On the other hand, nearly half (49\%) of special educators indicated that they shared the responsibility of educating students with disabilities with other educators in the school. A representative remark from this group was:

It is a community here and everyone plays a role. The teacher is responsible for instruction in the general education setting within a community of learners. As help is need[ed], it is provided, and we are a resource for that teacher. It isn't that is not my responsibility - it's that it is all of our responsibility.

A large subset of this group (24\%) described a team approach to service delivery in their school. One teacher's comments illustrate the feelings of others.

If you were to come into our classroom, I am a teacher with 46 students, with myself and 2 regular education teachers. We teach all together. Students don't differentiate between me, as the special educator, and the regular education teachers. I am just one teacher on a team. Inclusive settings create a team effort. These are our students not just my students. 
Other teachers talked about sharing their role with administrators, parents, and related service providers. There are eight special educators in this building so it is very supportive. It is a shared responsibility with the other teachers, parents, other support staff. It is a group effort. I am never really doing it alone.

The voices of the teachers conveying their perceptions of their positions provide a picture of rural special education that is both informative and instructive. There were several factors in the study, however, which may pose limitations to the reported results.

\section{Limitations}

The data are reported in a way that conveys the recurrent themes that emerged. Categories selected by $2 \%$ or fewer teachers are not reported. If a teacher's answer to a question included multiple themes, then the response was recorded in each respective category.

The validity of teacher responses may have been influenced by factors of time, trust, and the order of the questions (Tamur, 1992). Time constraints may have affected teachers' interpretations of the question and their answer. The limited time frame of the telephone interview may have exerted pressure on teachers to respond quickly to questions that involved complicated relationships and inadvertently encouraged teachers to respond with a perfunctory remark. Moreover, the method of interview delivery did not allow a level of trust to develop and teachers may have had limited investment in providing more than a superficial response. Nevertheless, many teachers did supply lengthy and candid answers and measures were taken to accurately record their perspectives. The sequence of the questions may have also influenced teachers' responses to include information about support and relationships. For example, questions about the advantages and challenges of teaching followed items pertaining to work-related support.

\section{Discussion}

The 204 special education teachers in this study expressed their perceptions of the benefits and challenges of their positions in rural schools. Some voiced concerns about the responsibilities of their position and professional isolation; however, others spoke of a caring school community that supported them personally and professionally. From this picture of rural special education, conclusions can be made that will assist rural administrators in facilitating positive working conditions in rural schools and potentially influence teacher satisfaction.

\section{Challenges to Special Education in Rural Schools}

The teachers in this national sample of rural special educators voiced many of the same concerns as their special education counterparts in urban areas (Billingsley, 2004a). Teachers discussed the challenges of providing services to their students given the constraints of time, budgets, scheduling, responsibilities (e.g., paperwork, co-teaching), and role confusion in inclusionary settings. These challenges have been discussed in the literature as contributors to teacher dissatisfaction and the attrition of teachers in the field of special education (Billingsley, Carlson, \& Klein, 2004; Brownell et al., 2005; Miller, Brownell, \& Smith, 1999; Stempien \& Loeb, 2002).

An additional challenge, which repeatedly surfaced in the analysis, was the sense of professional isolation. Comments conveying the lack of support from general education teachers, parents, and administrators were common. Moreover, half of the special educators reported that they felt they shouldered the entire responsibility for educating students with disabilities. Of concern, perceptions of professional isolation appear to have a relationship with lower levels of teacher satisfaction and job commitment (Billingsley, 2004b; Cooley \& Yovanoff, 1996; Westling, Herzog, Cooper-Duffy, Prohn, \& Ray, 2006).

\section{Benefits of Special Education in Rural Areas}

Despite inherent challenges, most special educators were largely satisfied with the instructional aspects of their position. Many of them felt supported in their role through relationships with others in their school and rural community. To illustrate this relationship between professional support and satisfaction, when commenting about what they liked best about their position, a number of special education teachers centered their remarks 
around the supportive community they had in their rural school and small town. Special educators described close knit-relationships among school staff and a greater sense of familiarity with students and their families. This broader knowledge of their students gave teachers the sense they could individualize instruction more effectively and improve student learning outcomes. In addition, half of the special education teachers stated they shared the responsibility of providing services to students with disabilities with other teachers including general education teachers, that teaching was a team effort. However, relationships between teachers were not always supportive. Consequently, special education and general education teachers may need training and administrative support to foster these potentially beneficial relationships.

\section{Implications}

In light of the results, the following recommendations would seem appropriate:

1. Administrators should provide teachers with opportunities for both formal and informal support. Such opportunities might take the form of common planning time or other meetings where general and special education teachers can gather, exchange information, problem solve, and discuss student related issues. Local and regional meetings and online connections among special educators can provide a vehicle to develop supportive relationships.

2. Administrators may need to facilitate conversations to help general and special education teachers clearly define their roles and responsibilities pertaining to the education of students with disabilities. Such delineation of roles has the potential to reduce role confusion and role conflict and support collaboration among general and special education teachers.

3. General education and special education teachers may require specific training in different types of co-teaching and how to negotiate collaborative relationships in an inclusive environment (Scruggs, Mastopieri \& McDuffie, 2007). Local or regional professional development or inservice training in co-teaching may help to form and sustain supportive relationships.
4. Administrators should provide special educators with support and flexibility with respect to the scheduling of the school day. Teachers should be able to meet the time demands of providing services to students as well as the administrative demands of the position.

5. Administrators should be supportive and resourceful, working with local, state, and federal agencies and funding sources, to help special educators provide the necessary services and technology for students with disabilities.

6. Administrators should provide special education teachers with assistance in the paperwork and clerical responsibilities to lighten the burden created by special education processes.

7. Pre-service teacher training programs, particularly those with a rural focus, need to prepare special educators to teach effectively in inclusionary settings. Pre-service teachers need specific pedagogy to know how to collaboratively plan with general education teachers and use evidence-based practices within the context of the curriculum (Brownell et al., 2010).

8. Rural schools may struggle to provide the services required by individualized programs. As a result, small schools may be forced to consolidate services among several districts (Hodge, \& Krumm, 2009). Federal and state organizations should provide financial support to maintain small, local schools and capitalize on the positive environments fostered there.

9. Future research may study the factors involved in a creating a shared sense of responsibility for special education among all teachers and the components that contribute to this type of essential teacher collaboration.

Much has been learned about the advantages and challenges of rural special education positions by listening to the teachers in this study. The results indicate that teachers and administrators in small, rural schools may be in a unique position to nurture important qualities in their school that matter. Creating a positive working environment has the potential to increase teacher satisfaction and, as a result, improve the quality of the education students with disabilities receive in rural schools. 


\section{References}

Berry, A. (2012). The relationship of perceived support to satisfaction and commitment for special education teachers in rural areas. Rural Special Education Quarterly, 31(1), 3-14.

Billingsley, B. (2004a). Promoting teacher quality and retention in special education. Journal of Learning Disabilities, 37(5), 370-376.

Billingsley, B. (2004b). Special education teacher retention and attrition: A critical analysis of the research literature. The Journal of Special Education, 38(1), 39-55.

Billingsley, B., Carlson, E., \& Klein, S. (2004). Working conditions and induction support of early career special educators. Exceptional Children, 70(3), 333 - 347.

Bornfield, G., Hall, N., Hall, P., \& Hoover, J. (1997). Leaving rural special education positions: It's a matter of roots. Rural Special Education Quarterly, 16(1), 30-37.

Brownell, M., Bishop, A., \& Sindelar, P. (2005). NCLB and the demand for highly qualified teachers: Challenges and solutions for rural schools. Rural Special Education Quarterly, 24(1), 9-14.

Brownell, M., Sindelar, P., Kieley, M., \& Danielson, L. (2010). Special education teacher quality and preparation: Exposing foundations, constructing a new model. Exceptional Children, 76(3), 357377.

Collins, T. (1999). Attracting and retaining teachers in rural areas. Charleston, WV: ERIC Clearinghouse on Rural and Small Schools.

Cooley, E., \& Yovanoff, P. (1996). Supporting professionals-at-risk: Evaluating interventions to reduce burnout and improve retention of special educators. Exceptional Children, 62(4), 336355.

Davis, M. (2002). Teacher retention and small rural school districts in Montana. The Rural Educator, 24(2), 45-52.

Downing, J., \& Peckham-Hardin, K. (2007). Supporting inclusive education for students with severe disabilities in rural areas. Rural Special Education Quarterly, 26(2), 10-15.

Gehrke, R., McCoy, K. (2007). Sustaining and retaining beginning special educators: It takes a village. Teaching and Teacher Education, 23, 490-500.

Gersten, R., Keating, T., Yovanoff, P., \& Harniss, M. (2001). Working in special education: Factors that enhance special educators' intent to stay. Exceptional Children, 67(4), 549-567.

Hodge, L., \& Krumm, B. (2009). NCLB: A study of its effect on rural schools - School administrators rate service options for students with disabilities. Rural Special Education Quarterly, 28(1), 20-27.

Huysman, J. (2008). Rural teacher satisfaction: An analysis of beliefs and attitudes of rural teachers' job satisfaction. The Rural Educator, 29(2), 3137.

Jimerson, L. (2005). Placism in NCLB - How rural children are left behind. Equity and Excellence in Education, 38(3), 211-219.

Ludlow, B., Conner, D., \& Schechter, J. (2005). Low incidence disabilities and personnel preparation for rural areas: Current status and future trends. Rural Special Education Quarterly, 24(3), 15-22.

Malloy, W., \& Allen, T. (2007). Teacher retention in a teacher resiliency-building rural school. The Rural Educator, 28(2), 19-27.

Miles, M., \& Huberman, A. (1994). Qualitative data analysis: An expanded sourcebook ( $2^{\text {nd }}$ ed.). Thousand Oaks, CA: Sage.

Miller, D., Brownell, M., \& Smith, S. (1999). Factors that predict teachers staying in, leaving, or transferring from the special education classroom. Exceptional Children, 65(2), 201218.

Monk, D. (2007). Recruiting and retaining high quality teachers in rural areas. The Future of Children, 17(1), 155-174.

Nagle, K., Hernandez, G., Embler, S., McLaughlin, M., \& Doh, F. (2006). Characteristics of effective elementary schools for students with disabilities. Rural Special Education Quarterly, 25(3), 3-12.

National Center for Education Statistics. (2006). National Center for Education Statistics common core of data public elementary and secondary school district universe (Version 1a). from http://nces.ed.gov/ccd/index.asp.I 
Provasnik, S., KewalRamani, A., Coleman, M., Gilbertson, L., Herring, W., \& Xie, Q. (2007). Status of education in rural America (NCES 2007-040). Washington, DC: National Center for Educational Statistics, Institute for Education Sciences, U.S. Department of Education.

Scruggs, T., Mastropieri, M., \& McDuffie, K. (2007). Co-teaching in inclusive classrooms: A metasynthesis of qualitative research. Exceptional Children, 73(4), 392-416.

Schwartzbeck, T., Prince, C., Redfield, D., Morris, H., \& Hammer, P. (2003). How are rural districts meeting the teacher quality requirements of No Child Left Behind? Retrieved from http://www.aasa.org/content.aspx?id=628\& terms $=$ How + are + rural + districts + meeting + the

+ teacher+quality + requirements $+o f+N o+$ Child + Left + Behind $\% 3 f+$.
Stempien, L., \& Loeb, R. (2002). Differences in job satisfaction between general education and special education teachers: Implications for retention. Remedial and Special Education, 23(5), 258-267.

Tamur, J., M. (1992). Asking questions and influencing answers: Questions about questions. New York: Russell Sage Foundations.

Westling, D., Herzog, M., Cooper-Duffy, K., Prohn, K., \& Ray, M. (2006). The teacher support program: A proposed resource for the special education profession and an initial validation. Remedial and Special Education, 27(3), 136147.

Whitaker, S. (2000). Mentoring beginning special education teachers and the relationship to attrition. Exceptional Children, 66(4), 546-566.

\section{About the Authors:}

Ann B. Berry PhD, is an Assistant Professor of Special Education, Department of Educational Leadership, Learning and Curriculum, Plymouth State University, Plymouth, NH. Dr. Berry is involved with teacher preparation and professional development in a rural region of New Hampshire. She has a strong interest in effective instruction for students with high incidence disabilities, and rural special education teacher retention. abberry@mail.plymouth.edu

Maggie Gravelle MSW, was a dedicated doctoral student and Research Specialist at the Center for Developmental Science at the University of North Carolina, Chapel Hill, NC. Prior to the publication of this manuscript, Maggie was tragically diagnosed with brain cancer that ultimately claimed her life. She was an integral part of the National Research Center on Rural Education Support where she is remembered as a bright, kind, dedicated young woman whose work was highly valued and respected. We definitely feel her absence.

This research was a supplemental study conducted by the National Research Center on Rural Education Support, supported by a grant from the Institute of Educational Sciences. 